\title{
Economic technology analysis of lte advanced pro dual spectrum licensed and unlicensed access using discounted cash flow methods
}

\author{
Setiyo Budiyanto ${ }^{1}$, Erman Al Hakim ${ }^{2}$, Fajar Rahayu ${ }^{3}$ \\ ${ }^{1,2}$ Department of Electrical Engineering, Universitas Mercu Buana, Indonesia \\ ${ }^{3}$ Department of Electrical Engineering, Universitas Pembangunan Nasional "Veteran", Jakarta, Indonesia
}

\begin{tabular}{|c|c|}
\hline Article Info & ABSTRACT \\
\hline Article history: & \multirow{10}{*}{$\begin{array}{l}\text { Since implementing the long term evolution (LTE) technology, the surge in } \\
\text { data service traffic has increased, causing an increase in demand spectrum, } \\
\text { which has resulted in gaps in capacity requirements. Wireless service } \\
\text { providers can respond to LTE technology updates. With LTE advanced pro } \\
\text { technology that utilizes unlicensed spectrum technology can provide solutions } \\
\text { to increase capacity and throughput. In this study, LTE advanced pro planning } \\
\text { by capacity method to find the number of eNodeB and using the discounted } \\
\text { cash flow method to analyze the feasibility of the costs to be invested in the } \\
\text { implementation of the LTE. The results of the four simulated scenarios } \\
\text { concluded that the number of eNodeB from the IV scenario with } 20 \mathrm{MHz} \\
\text { bandwidth at } 1800 \mathrm{MHz} \text { frequency and } 20 \mathrm{MHz} \text { bandwidth at } 5 \mathrm{GHz} \text { frequency } \\
\text { amounted to } 23 \text { sites, with a positive NPV value of } \$ 271,936.96 \text {, IRR of } \\
14.91 \% \text {, and for Payback Period occurred in the 3rd year. Thus the fourth } \\
\text { scenario is feasible to be implemented. }\end{array}$} \\
\hline Received Mar 25, 2020 & \\
\hline Revised Sep 25, 2020 & \\
\hline Accepted Dec 1, 2020 & \\
\hline Keywords: & \\
\hline Discounted cash flow & \\
\hline eNodeB & \\
\hline LTE Advanced pro & \\
\hline Planning by capacity & \\
\hline Techno-economics & \\
\hline
\end{tabular}

This is an open access article under the $\underline{C C B Y-S A}$ license.

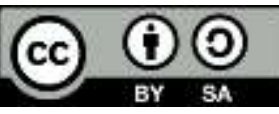

\section{Corresponding Author:}

Setiyo Budiyanto

Department of Electrical Engineering

Universitas Mercu Buana

Jl Meruya Selatan No. 1, Kembangan-Jakarta 11650 Indonesia

Email: sbudiyanto@mercubuana.ac.id

\section{INTRODUCTION}

Broadband technology in Indonesia continues to experience development, starting from the first generation technology $(1 \mathrm{G})$, up to the latest technology today, the fourth generation technology $(4 \mathrm{G})$, which has a speed of $100 \mathrm{Mbps}$ in theory [1]. 4G technology is often referred to as 4G LTE, with the presence of long term evolution (LTE) technology, data service traffic has experienced significant growth, many users of the previous generation switched to utilizing 4G LTE technology [2]. The higher internet speed is directly proportional to the activity of internet users, which causes an increase in demand spectrum such as downloads, data uploads, video streaming, social media, online games, mobile cloud. Which previously did not work well with $3 \mathrm{G}$ technology, but with 4G LTE, technology can run well [3]. Computer network technology as a medium of communication between devices has made significant progress in terms of communication media. This is one of the fastest-growing internet applications now [4]. On the other hand, data traffic has increased by $131 \%$ since 2011. This has prompted several cellular operators in Europe to invest in machine-to-machine communication. However, existing mobile networks cannot accommodate exponential growth in data traffic [5]. Other factors supporting the increase in traffic are increasingly affordable smartphones, internet access devices that are increasingly easy to use, and tariff wars between telecommunications providers, this has an 
impact on mobile data demand that continues to increase. While the spectrum is increasingly limited, which leads to a gap in capacity requirements. And is expected to decrease to minus $500 \mathrm{MHz}$ in 2020 [6]. By continuing to decline in the demand spectrum forecast in Indonesia, telecommunications providers must update LTE technology in anticipation of a higher demand spectrum, with LTE technology updating can increase capacity and throughput [7].

To improve the signal quality in the building necessary to add a new system called In-building coverage solution, which is a system with transmitter and receiver devices installed inside that aims to serve the needs of telecommunications in the building in terms of signal quality, coverage and its traffic capacity [8]. LTE advanced pro by utilizing license assisted access (LAA) technology is a technology that uses an unlicensed and licensed spectrum, which is expected an answer to the problem [9]. LTE advanced pro is the latest technology marker approved by 3GPP release 13 to show the next stage in development towards 5G [10]. With LTE advanced pro-technology, it can increase the efficiency of the spectrum and can increase network capacity and data speeds to be higher [11]. For the implementation of LTE Advanced Pro, mobile operators only need to upgrade existing eNodeB devices related to radio interface configuration to provide better cost-effective [12]. Also, it is necessary to have an investment cost analysis for the implementation of the tool, namely, capital expenditure (CAPEX) and operational expenditure (OPEX) [13].

The application of new technology requires a study of various aspects, such as technical aspects and economic aspects in order to measure the efficiency and investment feasibility of implementation [14]. In this study, the planning by the capacity method will use to determine the design of 4G LTE technology and then a techno-economic review is made using the discounted cash flow (DCF) method to measure the feasibility of the costs incurred in implementing the 4G LTE Advanced Pro [15].

\section{RESEARCH METHOD}

In this study, there are several stages of systematic and structured work established to obtain the expected results. The flow of this research can be known in Figure 1.

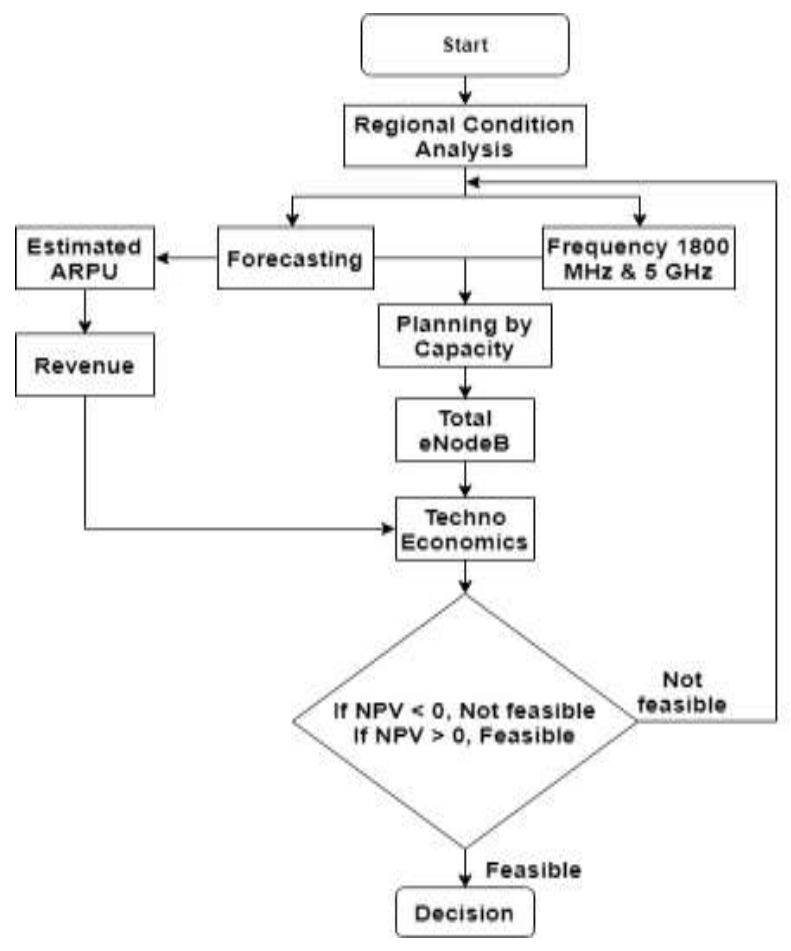

Figure 1. Research flow diagram

\subsection{Design analysis in technology \\ 2.1.1. Forecasting Number of LTE Users}

Forecasting of the population can calculate by the mathematical method of geometry projection shown in (1) as follows [20]. 


$$
P_{t}=\operatorname{Po}(1+X \%)^{n}
$$

Where, Pt is the number of population t-year, Jo is the initial population, $\mathrm{X} \%$ is the rate of population growth, and $\mathrm{n}$ is the number of years from 0 to $\mathrm{n}$.

Then to predict the amount of LTE users in the next five years with (2) as follows:

$$
\mathrm{P}=\mathrm{X} \% \mathrm{xPt}
$$

Where $\mathrm{P}$ is the number of cellular users, $\mathrm{Pt}$ is the number of population in the $\mathrm{t}$-year, and $\mathrm{X} \%$ is cellular teledensity $(\%)$.

\subsubsection{Network throughput}

To calculate the value of throughput per session in this study, using standard service model parameters from vendor Huawei [17]. Throughput per session can calculate using (3) as follows:

$$
\text { Troughput per session }=\mathrm{PPP} \text { session rate } \mathrm{x} \text { duty ratio } \mathrm{x} \text { bearer rate } \mathrm{x}\left[\frac{1}{1-\mathrm{BLER}}\right]
$$

Where, throughput per session is a minimum throughput requirement (Kbit), bearer rate is the data rate that must be provided by the service application layer (Kbps), PPP Session rate is the average duration of each service, duty ratio is the ratio of data sent in each session. And BLER is allowed in one session.

Single user throughput (SUT) is the activity of every internet user who is diverse in using LTE services [17]. By using the traffic parameters of the standard model from Huawei, and the standardization peak to average ratio, the value of single-user throughput can be calculated with (4).

$$
\text { SUT }(I P)=\frac{\left.\sum \text { (Troughput per session } \times \text { BHSA } \times \text { Penetration rate }\right) \times(1+\text { Peak to Average Ratio })}{3600}
$$

Where, single-user throughput (IP), BHSA is a service attempt in a busy hour, penetration Rate is the penetration of service usage by area, 3600 is time frame one hour, and Peak to average ratio is Estimated overload on traffic for dense urban peak to average ratio is $40 \%$, urban $20 \%$ [17].

Network throughput is the total number of traffic needs in the service area to meet the needs of all users [17]. To calculate network throughput using (5):

$$
\text { Network Throughput }=\text { Final user } \mathrm{x} \text { Single User Throughput }
$$

\subsubsection{Throughput per cell}

Calculating throughput per cell to determine the size of uplink and downlink in a cell. The steps to calculate the uplink and downlink MAC layer throughput, then calculate the average cell throughput based on the average SINR distribution [17]. After that, we can know the value of throughput per cell MAC throughput calculation using (6) and (7) follows:

$$
\begin{aligned}
& \text { UL MAC Throughput }+\mathrm{CRC}=(\mathrm{NRE}-\mathrm{NrReUL}) \times \text { Code bit } \times \text { Code rate } \times \text { Nrb } \times \mathrm{C} \times 100 \\
& \text { DL MAC Throughput }+\mathrm{CRC}=(\mathrm{NRE}-\mathrm{NcRE}-\mathrm{NrRE}) \times \text { Code bit } \times \text { Code rate } \times \text { Nrb } \times \mathrm{C} \times 1000
\end{aligned}
$$

Where, UL and DL MAC throughput is uplink and downlink MAC layer throughput, CRC is cyclic redundancy check (24 bits), NRE is the number of resistor elements (RE) in $1 \mathrm{~ms}$ (168), NcRE is the number of control channels resistor elements in $1 \mathrm{~ms}$ (36), NrRE is the number of reference signals resistor elements in $1 \mathrm{~ms}$ (12), NrReUL is the number of reference signals resistor elements in $1 \mathrm{~ms}$ in the uplink (24), Code bits are modulation efficiency, code rate is channel coding rate, $\mathrm{Nrb}$ is the number of block resource to be used, and $\mathrm{C}$ is the MIMO antenna model. distribution.

Calculate the value of cell average throughput using (8) based on parameters from the average SINR

$$
\text { Cell average throughput }(\mathrm{MAC})=\sum_{\mathrm{n}-1}^{\mathrm{n}-8} \operatorname{Pn} \times \mathrm{Rn}
$$

Where $\mathrm{n}$ is the number of cell throughput, Pn is SINR Probability, and Rn is Uplink / Downlink cell throughput. 
The amount of the throughput per cell will be calculated by converting the cell layer throughput (MAC) to the IP layer. This conversion process will use relative efficiency radio overhead [17]. Then the throughput per cell (IP) can be determined by the (9).

$$
\text { Throughput per cell (IP) = Cell average throughput (MAC) } x \text { Relative efficiency }
$$

Where relative efficiency is the parameter multiplication of radio over head with the parameter values as follows [18]; symbol $\mathrm{A}=0.993377, \mathrm{~B}=0.993421$, and $\mathrm{C}=0.993464$.

\subsubsection{The number of cells and eNodeB}

The next is to count the number of uplink and downlink cells. By using (10) and (11) the following formula calculates the number of cells and number of eNodeB:

$$
\begin{aligned}
& \text { Number of cell }=\frac{\text { Network throughput }}{\text { Throughput per cell }} \\
& \text { Number of eNodeB }=\frac{\text { Number of cell }}{\text { Number of cell per site }}
\end{aligned}
$$

\subsection{Economic analysis}

Economic analysis is the next stage after design analysis in technology. For the techno-economic scheme, several parameters that influence it include the final number of eNodeB, number of customers, revenue value, CAPEX and OPEX costs to find out the NPV, IRR, and Payback period [18]. While the assumptions of parameters from the economic scenario obtained Telkomsel's market share of 50\%, 35\% of traffic penetration [19]. And for the minimum attractive rate of return (MARR) value is $9 \%$, assuming that the margin due to risk is 3\% plus the Bank Indonesia interest rate in 2019 of $6 \%$ [20].

\subsubsection{Average revenue per user}

Average revenue per user (ARPU) is a measure to find out the average amount of income obtained by telecommunications companies from consumers. To calculate the ARPU value, first, calculate the ARPU growth every year [24]. To calculate ARPU growth using the calculate compound annual growth (CAGR) formula as in (12), which is used to calculate ARPU growth [22].

$$
\text { CAGR }=\left(\frac{\text { Initial value }}{\text { The last value }}\right)^{1 / n}-1
$$

Where $\mathrm{n}$ is the number of years.

After getting ARPU growth, the next step is to calculate the number of ARPU with (13).

$$
\text { ARPU }=(1+\text { Cgrowth }) \times \text { ARPU } n-1
$$

Where $(1+$ Cgrowth $)$ is the percentage of growth/decline, ARPU n-1 is the ARPU of the previous year.

\subsubsection{Revenue}

Revenue is a profit that is obtained by the company, but not from investment results within a specified period [21]. With use (14) the revenue value can calculate.

$$
\text { Revenue }=\text { Number of customers } \mathrm{x} \text { ARPU }
$$

\subsubsection{Net present value}

The net present value (NPV) is a widely used model in measuring the feasibility of a project, which takes into account the overall cash flow pattern of investment, about to time, based on a specific discount rate [23]. Where the value of cash flow from the previous period, the profit and loss is taken from the 2018 and 2017 annual reports. To calculate the NPV value using the (15) follows.

$$
\mathrm{NPV}=\sum_{\mathrm{t}=1}^{\mathrm{n}} \frac{\mathrm{CFt}}{(1+\mathrm{i})^{\mathrm{t}}}
$$

Where $\mathrm{CFt}$ is the annual cash flow in the period $\mathrm{t}, \mathrm{i}$ is the interest rate, Co is the initial investment in the zero year, $\mathrm{n}$ is the number of years, and $\mathrm{t}$ is the $\mathrm{t}$-year. 


\subsubsection{Internal rate of return}

Internal rate of return (IRR) is an investment calculation method according to the interest rate that equates the present value of the future proceeds with the current value of net cash receipts in the future [17]. The following (16) is a formula for calculating IRR values.

$$
\text { Co }=\sum_{\mathrm{t}=0}^{\mathrm{n}} \frac{\mathrm{CFt}}{(1+\mathrm{IRR})^{\mathrm{t}}}
$$

Where, Co is the initial investment in the zero year, $\mathrm{n}$ is the number of years, and $\mathrm{t}$ is the $\mathrm{t}$ year.

\subsubsection{Payback period}

Payback period (PBP) is a method of evaluating the feasibility of investment that can return within a period [25]. By using (17), the following that how long an investment can return:

$$
\text { Payback Period }=\sum_{\mathrm{t}=1}^{\mathrm{T}} \frac{\mathrm{CCFt}}{(1+\mathrm{r})^{\mathrm{t}}}
$$

Where, $\mathrm{T}$ is time, $\mathrm{r}$ is discount rate and for payback period estimation $\mathrm{r}$ was zero.

\section{RESULTS AND ANALYSIS}

\subsection{LTE planning by capacity}

Capacity by planning is a method for determining network scale based on capacity requirements, capacity planning used to determine the features of different regions and bandwidths. Central Jakarta has the characteristics of urban and urban dense areas [16]. According to its characteristics, central Jakarta divided into two types of urban and urban dense areas with a total productive age of central Jakarta in 2019 for urban area types is 145218 people and for urban dense totalling 687465 people [16].

At this stage, the number of LTE users will calculate for the next five years. With this data, an LTE Advanced pro network will plan. With the results of calculations for the type of dense urban areas and urban LTE users in 2023 totaled 127134 people and 26855 people. After knowing the forecasting of the number of subscribers for 5 years, then calculating the Network throughput, the first step is to find the value of throughput per session as in Table 1.

\begin{tabular}{|c|c|c|c|c|c|c|c|c|c|c|}
\hline \multirow[b]{2}{*}{ Traffic Parameters } & \multicolumn{4}{|c|}{ Uplink } & \multicolumn{4}{|c|}{ Downlink } & \multirow{2}{*}{$\begin{array}{c}\text { Uplink } \\
\text { Throughp } \\
\text { ut } \\
\text { /Session } \\
\text { (Kbit) }\end{array}$} & \multirow[b]{2}{*}{$\begin{array}{c}\text { Downlink } \\
\text { Throughput } \\
\text { /Session } \\
\text { (Kbit) }\end{array}$} \\
\hline & $\begin{array}{c}\text { Bearer } \\
\text { Rate } \\
\text { (Kbps) }\end{array}$ & $\begin{array}{c}\text { PPP } \\
\text { Session } \\
\text { Time } \\
\text { (s) }\end{array}$ & $\begin{array}{c}\text { PPP } \\
\text { Session } \\
\text { Duty } \\
\text { Ratio }\end{array}$ & $\begin{array}{l}\text { BL } \\
\text { ER }\end{array}$ & $\begin{array}{c}\text { Bearer } \\
\text { Rate } \\
\text { (Kbps) }\end{array}$ & $\begin{array}{c}\text { PPP } \\
\text { Sesion } \\
\text { Time (s) }\end{array}$ & $\begin{array}{c}\text { PPP } \\
\text { Session } \\
\text { Duty } \\
\text { Ratio }\end{array}$ & $\begin{array}{l}\text { BL } \\
\text { ER }\end{array}$ & & \\
\hline VoIP & 26.90 & 80 & 0.4 & 0.01 & 26.9 & 80 & 0.4 & 0.01 & 869.49 & 869.49 \\
\hline Video Phone & 62.53 & 70 & 1 & 0.01 & 62.53 & 70 & 1 & 0.01 & 4421.31 & 4421.31 \\
\hline Video Conference & 62.53 & 1800 & 1 & 0.01 & 62.53 & 1800 & 1 & 0.01 & 113690.9 & 113690.91 \\
\hline Real Time Gaming & 31.26 & 1800 & 0.2 & 0.01 & 125.06 & 1800 & 0.4 & 0.01 & 11367.27 & 90952.73 \\
\hline Streaming Media & 31.26 & 3600 & 0.05 & 0.01 & 250.11 & 3600 & 0.95 & 0.01 & 5683.64 & 864016.36 \\
\hline IMS Signalling & 15.63 & 7 & 0.2 & 0.01 & 15.63 & 7 & 0.2 & 0.01 & 22.1 & 22.1 \\
\hline Web Browsing & 62.53 & 1800 & 0.05 & 0.01 & 250.11 & 1800 & 0.05 & 0.01 & 5684.55 & 22737.27 \\
\hline File Transfer & 140.69 & 600 & 1 & 0.01 & 750.34 & 600 & 1 & 0.01 & 85266.67 & 454751.51 \\
\hline Email & 140.69 & 50 & 1 & 0.01 & 750.34 & 15 & 1 & 0.01 & 7105.56 & 11368.79 \\
\hline P2P File Sharing & 250.1 & 1200 & 1 & 0.01 & 750.34 & 1200 & 1 & 0.01 & 303151.51 & 909503.1 \\
\hline
\end{tabular}

Table 1. Throughput per session for service model traffic [12]

Then calculating the single-user throughput that refers to the traffic model parameters as in Table 2 using (4), the value of throughput per session is calculated based on each endpoint. The value of network throughput is in accordance with (5), the results of network throughput calculations are shown in Table 3.

To calculate the capacity of uplink and downlink cells refers to the average SINR distribution parameter for $1800 \mathrm{MHz}$ frequency and frequency of $5 \mathrm{GHz}$, using four bandwidths of $20 \mathrm{MHz}(\mathrm{Nbr}=100)$, $15 \mathrm{MHz}(\mathrm{Nbr}=75) 10 \mathrm{MHz}(\mathrm{Nbr}=50)$, and $5 \mathrm{MHz}(\mathrm{Nbr}=25)$, with a bandwidth of $20 \mathrm{MHz}(\mathrm{Nbr}=100)$, using (6) and (7) with the following calculation results in Table 4 and Table 5. By using (8) and SINR parameters in the SINR average distribution table, the average cell throughput value can determine. Table 6 follows the amount of cell average throughput calculated. 
Table 2. Single user throughput [12]

\begin{tabular}{|c|c|c|c|c|c|c|c|c|}
\hline \multirow[t]{2}{*}{ User Behavor } & \multicolumn{2}{|c|}{ Dense Urban } & \multicolumn{2}{|c|}{ Single User Throughput } & \multicolumn{2}{|c|}{ Urban } & \multicolumn{2}{|c|}{ Single User Throughput } \\
\hline & $\begin{array}{l}\text { Penetration } \\
\text { Ratio }\end{array}$ & $\begin{array}{l}\mathrm{BH} \\
\mathrm{SA}\end{array}$ & Uplink & Downlink & $\begin{array}{c}\text { Penetration } \\
\text { Ratio }\end{array}$ & $\begin{array}{l}\mathrm{BH} \\
\mathrm{SA}\end{array}$ & Uplink & Downlink \\
\hline VoIP & $100 \%$ & 1.4 & 1704.21 & 1704.21 & $100 \%$ & 1.3 & 1356.412 & 1356.412 \\
\hline Video Phone & $20 \%$ & 0.2 & 247.5935 & 247.5935 & $20 \%$ & 0.16 & 169.778 & 169.7784 \\
\hline Video & $20 \%$ & 0.2 & 6366691 & 6366.691 & $15 \%$ & 0.15 & 3069.655 & 3069.655 \\
\hline $\begin{array}{l}\text { Conference } \\
\text { Real Time } \\
\text { Gaming }\end{array}$ & $30 \%$ & 0.2 & 954.8509 & 7640.029 & $20 \%$ & 0.2 & 545.629 & 4365.731 \\
\hline Streaming Media & $15 \%$ & 0.2 & 238.7127 & 36288.69 & $15 \%$ & 0.15 & 153.458 & 23328.44 \\
\hline IMS Signalling & $40 \%$ & 5 & 61.88848 & 61.88848 & $30 \%$ & 4 & 31.8283 & 31.8283 \\
\hline Web Browsing & $100 \%$ & 0.6 & 4775.018 & 19099.31 & $100 \%$ & 0.4 & 2728.582 & 10913.89 \\
\hline File Trnsfer & $20 \%$ & 0.3 & 7162.4 & 38199.13 & $20 \%$ & 0.2 & 4092.8 & 21828.07 \\
\hline Email & $10 \%$ & 0.4 & 397.9111 & 636.6521 & $10 \%$ & 0.3 & 255.8 & 409.276 \\
\hline P2P File Sharing & $20 \%$ & 0.2 & 16976.48 & 50932.17 & $20 \%$ & 0.3 & 21826.91 & 65484.22 \\
\hline \multicolumn{3}{|c|}{ Single User Throughput in Busy Hours } & 1373.25 & 5691.94 & & & 255.12 & 976.9 \\
\hline
\end{tabular}

Table 3. Network throughput

\begin{tabular}{cccc}
\hline \multirow{2}{*}{ No } & \multirow{2}{*}{ Regional Type } & \multicolumn{2}{c}{ Network Throughput (Mbps) } \\
& & Uplink & Downlink \\
\hline 1 & Dense Urban & 1373.25 & 5691.94 \\
2 & Urban & 255.12 & 976.9 \\
\hline
\end{tabular}

Table 4. Results of calculating $1800 \mathrm{MHz}$ cell capacity

\begin{tabular}{cccc}
\hline No & $\begin{array}{c}\text { Modulation Coding } \\
\text { Scheme }\end{array}$ & $\begin{array}{c}\text { UL MAC Layer } \\
\text { Throughput (Mbps) }\end{array}$ & $\begin{array}{c}\text { DL MAC Layer } \\
\text { Throughput (Mbps) }\end{array}$ \\
\hline 1 & QPSK 1/3 & 19.008 & 15.84 \\
2 & QPSK 1/2 & 28.8 & 24 \\
3 & QPSK 2/3 & 38.592 & 32.16 \\
4 & 16QAM 1/2 & 57.6 & 48 \\
5 & 16QAM 2/3 & 77.184 & 64.32 \\
6 & 16QAM 4/5 & 92.16 & 76.8 \\
7 & 64QAM 1/2 & 86.4 & 72 \\
8 & 64QAM 2/3 & 115.776 & 96.48 \\
\hline
\end{tabular}

Table 5. Results of calculation of $5 \mathrm{GHz}$ cell capacity

\begin{tabular}{|c|c|c|c|c|c|c|c|c|c|}
\hline \multirow[t]{2}{*}{ No } & \multirow{2}{*}{$\begin{array}{c}\text { Modulation } \\
\text { Coding Scheme }\end{array}$} & \multicolumn{2}{|c|}{$\begin{array}{c}\text { Bandwidth } 20 \mathrm{MHz} \text { MAC } \\
\text { Throughput (Mbps) }\end{array}$} & \multicolumn{2}{|c|}{$\begin{array}{c}\text { Bandwidth } 15 \mathrm{MHz} \text { MAC } \\
\text { Throughput (Mbps) }\end{array}$} & \multicolumn{2}{|c|}{$\begin{array}{c}\text { Bandwidth } 10 \mathrm{MHz} \text { MAC } \\
\text { Throughput (Mbps) }\end{array}$} & \multicolumn{2}{|c|}{$\begin{array}{c}\text { Bandwidth } 5 \mathrm{MHz} \text { MAC } \\
\text { Throughput (Mbps) }\end{array}$} \\
\hline & & Uplink & Downlink & Uplink & Downlink & Uplink & Downlink & Uplink & Downlink \\
\hline 1 & QPSK 1/3 & 19.008 & 17.424 & 14.25 & 13.068 & 9.504 & 8.712 & 4.752 & 4.356 \\
\hline 2 & QPSK 1/2 & 28.8 & 26.4 & 21.6 & 19.8 & 14.4 & 13.2 & 7.2 & 6.6 \\
\hline 3 & QPSK 2/3 & 38.592 & 35.376 & 28.944 & 26.532 & 19.296 & 17.688 & 9.648 & 8.844 \\
\hline 4 & 16QAM $1 / 2$ & 57.6 & 52.8 & 43.2 & 39.6 & 28.8 & 26.4 & 14.4 & 13.2 \\
\hline 5 & 16QAM 2/3 & 77.184 & 70.752 & 57.888 & 53.064 & 38.592 & 35.376 & 19.296 & 17.688 \\
\hline 6 & 16QAM 4/5 & 92.16 & 84.48 & 69.12 & 63.36 & 46.08 & 42.24 & 23.04 & 21.12 \\
\hline 7 & 64QAM 1/2 & 86.4 & 79.2 & 64.8 & 59.4 & 43.2 & 39.6 & 21.6 & 19.8 \\
\hline 8 & 64QAM 2/3 & 115.776 & 106.128 & 86.832 & 79.596 & 57.888 & 53.064 & 28.944 & 26.532 \\
\hline
\end{tabular}

Table 6. Cell average throughput

\begin{tabular}{cccc}
\hline No & Frequency & $\begin{array}{c}\text { Uplink Cell Average } \\
\text { Throughput (MAC) }\end{array}$ & $\begin{array}{c}\text { Downlink Cell Average } \\
\text { Throughput (MAC) }\end{array}$ \\
\hline 1 & $1800 \mathrm{MHz}$ dengan bandwidth $20 \mathrm{MHz}$ & 61.246 & 51.1 \\
2 & $5 \mathrm{GHz}$ dengan bandwidth $20 \mathrm{MHz}$ & 50.451 & 46.247 \\
3 & $5 \mathrm{GHz}$ dengan bandwidth $15 \mathrm{MHz}$ & 37.837 & 34.685 \\
4 & $5 \mathrm{GHz}$ dengan bandwidth $10 \mathrm{MHz}$ & 24.731 & 22.671 \\
5 & $5 \mathrm{GHz}$ dengan bandwidth $5 \mathrm{MHz}$ & 12.613 & 11.562 \\
\hline
\end{tabular}

After the value of the cell average throughput (MAC) is converted to the IP layer throughput. By using (9) throughput per cell can be known, as in Table 7. By (10), we can find out the number of cell carrier aggregation $1800 \mathrm{MHz}$ with a bandwidth of $20 \mathrm{MHz}$ and $5 \mathrm{GHz}$ frequency with a bandwidth of $20 \mathrm{MHz}, 15$ $\mathrm{MHz}, 10 \mathrm{MHz}$, and $5 \mathrm{MHz}$. The results of cell capacity calculations from downlink and uplink are listed in Table 8 . 
Referring to the results of the calculation of the number of cells that have obtained as in Table 8, the estimate of the number of eNodeB will be used (11). Then the calculation results are as in Table 9. From the number of eNodeB obtained from the calculation, the highest number of eNodeB is chosen, which is the total value of eNodeB [16].

Table 7. Cell capacity for every frequency

\begin{tabular}{ccc}
\hline Frequency & \multicolumn{2}{c}{ Throughput per cell } \\
& Uplink & Downlink \\
\hline $1800 \mathrm{MHz} \& 5 \mathrm{GHz}$ & 109.51 & 95.44 \\
$1800 \mathrm{MHz} \& 5 \mathrm{GHz}$ & 97.14 & 84.11 \\
$1800 \mathrm{MHz} \& 5 \mathrm{GHz}$ & 84.78 & 72.77 \\
$1800 \mathrm{MHz} \& 5 \mathrm{GHz}$ & 72.41 & 61.43 \\
\hline
\end{tabular}

Table 8. Number of cells carrier aggregation $1800 \mathrm{MHz} \& 5 \mathrm{GHz}$

\begin{tabular}{|c|c|c|c|c|c|c|c|c|c|c|c|}
\hline \multirow[t]{2}{*}{ Regional Type } & \multirow[t]{2}{*}{ LTE Users } & \multicolumn{2}{|c|}{$\begin{array}{l}\text { Network Thoroughput } \\
\text { (Mbps) }\end{array}$} & \multicolumn{2}{|c|}{$\begin{array}{l}\text { Bandwidth of } \\
20 \& 20 \mathrm{MHz}\end{array}$} & \multicolumn{2}{|c|}{$\begin{array}{l}\text { Bandwidth of } \\
20 \& 15 \mathrm{MHz}\end{array}$} & \multicolumn{2}{|c|}{$\begin{array}{l}\text { Bandwidth of } \\
20 \& 10 \mathrm{MHz}\end{array}$} & \multicolumn{2}{|c|}{$\begin{array}{l}\text { Bandwidth of } \\
20 \& 5 \mathrm{MHz}\end{array}$} \\
\hline & & UL & DL & UL & DL & UL & $\mathrm{DL}$ & UL & DL & UL & DL \\
\hline Dense Urban & 127134 & 1373.3 & 5684.5 & 13 & 60 & 14 & 68 & 16 & 78 & 19 & 93 \\
\hline Urban & 26855 & 244.3 & 934.7 & 2 & 10 & 3 & 11 & 3 & 13 & 4 & 15 \\
\hline Total & 147338 & 1564.2 & 6373.6 & 15 & 70 & 17 & 79 & 19 & 91 & 23 & 108 \\
\hline
\end{tabular}

Table 9. Number of eNodeB carrier aggregation $1800 \mathrm{MHz} \& 5 \mathrm{GHz}$

\begin{tabular}{|c|c|c|c|c|c|c|c|c|c|c|c|}
\hline \multirow[t]{2}{*}{ Regional Type } & \multirow[t]{2}{*}{ LTE Users } & \multicolumn{2}{|c|}{$\begin{array}{l}\text { Network Thoroughput } \\
\text { (Mbps) }\end{array}$} & \multicolumn{2}{|c|}{$\begin{array}{l}\text { Bandwidth of } \\
20 \& 20 \mathrm{MHz}\end{array}$} & \multicolumn{2}{|c|}{$\begin{array}{l}\text { Bandwidth of } \\
20 \& 15 \mathrm{MHz}\end{array}$} & \multicolumn{2}{|c|}{$\begin{array}{l}\text { Bandwidth of } \\
20 \& 10 \mathrm{MHz}\end{array}$} & \multicolumn{2}{|c|}{$\begin{array}{l}\text { Bandwidth of } \\
20 \& 5 \mathrm{MHz}\end{array}$} \\
\hline & & UL & DL & UL & DL & UL & DL & UL & DL & UL & DL \\
\hline Total eNodeB & 147338 & 1564.2 & 6373.6 & 5 & 23 & 6 & 27 & 6 & 30 & 7 & 36 \\
\hline
\end{tabular}

\subsection{Techno economic analysis}

The discounted cash flow (DCF) method was chosen because it will provide an overall overview to identify inputs in the form of cost structures (CAPEX, OPEX, and Revenue) and on the output parameters, namely IRR, NPV, and PBP [26].

\subsubsection{Capital expenditure}

Each table has a quantity of eNodeB so, it has a different investment value, as in Table 10 is the Assumption of Initial Capital Expenditure, the following scenario simulation used:

Table 10. Assumption of initial capital expenditure for scenario

\begin{tabular}{|c|c|c|c|c|c|}
\hline Equipment & Price (USD) & Scenario 1 & Scenario II & Scenario III & Scenario IV \\
\hline Upgrade eNodeB & $\$ 22,105.8$ & 36 & 30 & 27 & 23 \\
\hline CME LTE & $\$ 1750$ & 36 & 30 & 27 & 23 \\
\hline Installation \& Commisioning & $\$ 5,333.4$ & 36 & 30 & 27 & 23 \\
\hline Device LTE & $\$ 33,609.4$ & 36 & 30 & 27 & 23 \\
\hline Maintenance & $1.5 \%$ total cost & 1 & 1 & 1 & 1 \\
\hline \multicolumn{2}{|c|}{ Total initial investment } & $\$ 2,477,417.79$ & $\$ 2,100,624.21$ & $\$ 1,912,227.42$ & $\$ 1,661,031.7$ \\
\hline
\end{tabular}

\subsubsection{Operational expenditure}

Operational expenditure (OPEX) is an allocation of operating and maintenance expenses needed in operating an LTE network, the value is as shown in Table 11.

Table 11. Estimated cost of OPEX LTE advanced pro

\begin{tabular}{cccccc}
\hline Years & Marketing & General and Administration & Human Resources & Oprational \& Maintenance & Total OPEX \\
\hline 2019 & 2143.35 & 7125.22 & 76987.53 & 144690.15 & 250178.55 \\
2020 & 45797.36 & 15265.79 & 80729.13 & 3976.29 & 145768.57 \\
2021 & 88450.79 & 29483.60 & 98601.00 & 8161.86 & 395947.12 \\
2022 & 166185.92 & 55395.31 & 103393.00 & 14230.93 & 339205.16 \\
2023 & 265455.92 & 88485.31 & 108417.90 & 40343.35 & 502702.48 \\
\hline
\end{tabular}




\subsubsection{Average revenue per user}

Using (12) and (13) with ARPU values in 2019, then the ARPU value can be known. Table 12 is the result of the ARPU calculation up to 2023.

Table 12. ARPU value

\begin{tabular}{cccccc}
\hline \multicolumn{7}{c}{ ARPU Data For the Period 2019 to 2023 } \\
\hline Years & 2019 & 2020 & 2021 & 2022 & 2023 \\
Blended ARPU & 46000 & 46644 & 47297 & 47959 & 48630 \\
\hline
\end{tabular}

\subsubsection{Revenue}

By using the ARPU value in Table 12 with the number of Telkomsel LTE subscribers, the revenue value can known. Following is Table 13 of the calculation results of (14).

Table 13. Revenue LTE advanced pro

\begin{tabular}{cccc}
\hline Years & Predicted Number of LTE Customers & Predicted ARPU & Revenue $(\$)$ \\
\hline 2019 & 135218 & 46.000 & 453470.27 \\
2020 & 136719 & 46.644 & 464923.12 \\
2021 & 138237 & 47.297 & 476666.22 \\
2022 & 139771 & 47.959 & 488701.50 \\
2023 & 153989 & 48.630 & 545946.94 \\
\hline
\end{tabular}

\subsubsection{Techno-economic feasibility}

Discounted cash flow (DCF) based on DCF calculations to determine the internal rate of return (IRR) output, Payback period (PBP), and net present value (NPV). If the NPV value > 0 , then the implementation of LTE Advanced Pro is feasible because the company gets a benefit. If NPV $=0$, the company will not get any loss or profit. And if NPV $<0$, then the implementation of LTE Advanced Pro is not feasible because the company will not be able to profit. From the above data Table 14, NPV, IRR, and PBP can be calculated by (15), (16), and (17). The following Table 15 is the result of a techno-economic feasibility analysis:

Table 14. Investment value and net cash

\begin{tabular}{lccccc}
\hline & First Investment & Second Investment & Third Investment & Fourth Investment & Net Cash Flow (\$) \\
\hline 0 Years & $\$ 2,477,417.79$ & $\$ 2,100,624.21$ & $\$ 1,912,227.42$ & $\$ 1,661,031.7$ & \\
$1^{\text {st }}$ year & & & & & $\$ 453,470.27$ \\
$2^{\text {nd }}$ year & & & & & $\$ 476,143.78$ \\
$3^{\text {rd }}$ year & & & & $\$ 499,950.97$ \\
$4^{\text {th }}$ year & & & & $\$ 524,948.52$ \\
$5^{\text {th }}$ year & & & & $\$ 551,195.95$ \\
\hline
\end{tabular}

Table 15. Economic feasibility analysis of NPV, IRR, and PBP

\begin{tabular}{ccccc}
\hline Scenario & NPV & IRR & PBP & Summary \\
\hline Scenario I & $-\$ 318,035.6 \mathrm{NPV}<0$ & $0.37 \%<$ MARR 9\% & 4 years 9 months & Not feasible because NPV $<0$ \\
Scenario II & $\$ 58,758.02 \mathrm{NPV}>0$ & $5.97 \%<$ MARR 9\% & 4 years 2 months & Not feasible because IRR 9\% $>5.97 \%$ \\
Scenario III & $\$ 247,154.81 \mathrm{NPV}>0$ & $9.40 \%>$ MARR 9\% & 3 years 9 months & feasible \\
Scenario IV & $\$ 498,350.53 \mathrm{NPV}>0$ & $14.91 \%>$ MARR 9\% & 3 years 4 months & feasible \\
\hline
\end{tabular}

\section{CONCLUSION}

Based on the results of the analysis presented in the previous chapters, conclusions can draw regarding the technological and techno-economic review of the implementation of the LTE advanced pro network in Jakarta. For the third scenario the number of eNodeB used is 27 sites, for analysis of discounted cash flow with an initial investment of $\$ 1,912,227.42$, NPV is $\$ 247,154.81 \mathrm{NPV}>0$, IRR value of 9.40\%> MARR of 9\% while for payback period for three years and nine-month of the results of the third scenario is feasible to be implemented. Whereas for the fourth scenario the number of eNodeB used is 23 sites, for the analysis of discounted cash flow with an initial investment of \$1,661,031.7 NPV value of \$498,350.53 NPV >0, for an IRR value of $14.91 \%>$ MARR of $9 \%$. While the payback period was three years and four months, then the fourth scenario is declared to be eligible to be implemented. With this result, the implementation of LTE Advanced pro in central Jakarta is said to be feasible. 


\section{ACKNOWLEDGEMENTS}

Alhamdulillah, all praise belongs only to Allah SWT. The journal labeled is "Economic technology Analysis of LTE Advanced pro dual spectrum licensed and unlicensed access using discounted cash flow Methods," as a condition of completing the Research at Universitas Mercu Buana, Jakarta.

\section{REFERENCES}

[1] J. Robinson and M. Sivakumaran, "Accelerating Indonesia's digital economy: Assigning the $700 \mathrm{MHz}$ band to mobile broadband", GSMA, 2018.

[2] J.Morley, K. Widdicks, and M. Hazas,"Digitalisation, Energy and Data Demand: The Impact of Internet Traffic on Overall and Peak Electricity Consumption," Energy Reasearch \& Social Science, vol. 38, pp. 128-137, 2018, doi: 10.1016/j.erss.2018.01.018.

[3] S. Budiyanto, B. Nugraha, and D.W. Astuti“Performance Test of Various Types of Antenna Arrays in Real Propagation Environment," IOP Conf.Series: Materials Science and Engineering, vol. 105, 2016, 012015 doi:10.1088/1757-899X/105/I/012015.

[4] S. Budiyanto, M. Asvial, and D. Gunawan, "Improved performance of hybrid algorithm for 3G-WiFioffload networks," Jurnal Teknologi, vol. 78, pp. 5-9, 2016, doi: 10.11113/jt.v78.8780.

[5] S. Budiyanto, A. Nugroho, "A New Model of Genetic Zone Routing Protocol (GZRP): The Process of Load Balancing and Offloading on The UMTS-IEEE 802.11 g Hybrid Networks". TELKOMNIKA (Telecommunication Computing Electronics and Control), vol. 15, no. 2, pp. 598-605, 2017.

[6] S. Budiyanto, M. Asvial, and D. Gunawan, "Implementation Dedicated Sensing Receiver (DSR) in 3G-WiFi Offload", International Conference on Smart Green Technology in Electrical and Information Systems (ICSGTEIS), 2014, pp. 37-42, doi: 10.1109/ICSGTEIS.2014.7038731.

[7] S. Budiyanto, A.Nugroho, B.Nugraha, and F.Sirait, "IP over radio: A performance evaluation for internet of things system with various data transmission," Journal of Computational and Theoretical Nanoscience, 23(6): 5581-5583, doi: 10.1166/asl.2017.7426.

[8] S. Budiyanto, H. C. Sihombing, F. Rahayu IM, "Depression and anxiety detection through the Closed-Loop method using DASS-21," TELKOMNIKA (Telecommunication Computing Electronics and Control), vol. 17, no. 4, pp. 2087-2097, 2019, doi: 10.12928/telkomnika.v17i4.12619.

[9] M. Sauter and Wiley, "From GSM to LTE-Advanced pro and 5G," Thrid Edition.Cologne:John wiley \& Sons Ltd, 2017, doi: 10.1002/9781119714712.

[10] D. Mavrakis, "Accelerating the Path to 5G with LTE Advanced Pro", Qualcomm, 2018.

[11] U. Zareen, "LTE-Advanced: Techno Economical Prespective," Universal Journal of Communications and Network, pp. 93-100, 2014.

[12] Huawei Technology co. Ltd, 2014.

[13] E.J.Oughton and Z.Frias,"The cost, coverage and rollout implications of 5G infrastructure in Britain," Telecommunication Policy, DOI: 10.1016/j.telpol.2017.07.009.

[14] M.Mehrnoush, V.Sathya, S. Roy, and M. Ghosh,"Analytical Modeliing of Wi-fi and LTE-LAA Coexistence: Throughput and Impact of Energy Detection Threshold," IEEE/ACM Transactions on Networking 2018, vol, 26, Issue: 4, Aug. 2018, doi: 10.1109/TNET.2018.2856901.

[15] G.H.Mako,"Techno-Economic Investigation of LTE-Advanced Deployment for Addis Ababa, Ethiopia," Thesis. Addis Ababa Institut of Technology, Ethiopia, 2018, doi: 10.13140/RG.2.25802.11205.

[16] M. Asvial, S. Budiyanto, and D. Gunawan,"An Intelligent Load Balancing and Offloading in 3G-WiFi Offload Network Using Hybrid and Distance Vector Algorithm," IEEE Symposium on Wireless Technology and Applications (ISWTA), 2014, doi: 10.1109/ISWTA.2014.6981191.

[17] S. Budiyanto, and E.A. Hakim, "Feasibility Analysis the Implementation of the Dual Spectrum Licensed and Unlicensed Enhanced License Assisted Access (eLAA) on LTE Networks with the Techno Economic Method," 2nd International Conference on Broadband Communications, Wireless Sensors and Powering (BCWSP), doi: 10.1109/BCWSP50066.202.9249472.

[18] A. Jha and D. Saha. "Techno-Commercial Feasibility Analysis of 4G Mobile Services in India," IIMB Management Review, pp. 182-199, 2016, doi: 10.1016/j.iimb.2019.03.007.

[19] R. Galih, "Carrier Aggregation Technique to Improve Capacity in LTE-Advanced Network," TELKOMNIKA (Telecommunication Computing Electronics and Control), vol. 14, no. 1, pp. 199-128, 2016, doi: 10.12928/TELKOMNIKA.v14i1.2668.

[20] M. Suryanegara, "The Forecasting Model of 4G LTE Implementation in Indonesia", IEEE International Conference on Management of Innovation and Technologi, 2014, pp. 461-466, doi: 10.1109/ICMIT.2014.6942471.

[21] Lte Radio Network Capacity Dimensioning, Huawei tecnologies Co.Ltd.2013.

[22] E. Feghi, Z. S. Zubi, A. Jamil, and H. Algabroun,"LTE Technology Deployment Strategy for Mobile Telecom Operators": A Techno-Economic Analysis, 2014.

[23] D. Negash, "Techno-Economic Analysis of LTE Deployment Scenarios for Emerging City: A Case of Adama Ethiopia,” Thesis, Addis Ababa Institut of Technology, Ethiopia, 2018, doi: 10.1007/978-3-030-26630-1_18.

[24] S. Budiyanto, and E.A. Hakim, "Factor Analysis of Media Panel on Mobile Phone Average Revenue Per User by Telecommunication Companies," Journal of The Korean Data Analysis Society (JKDAS), doi: 10.37727/jkdas.2018.20.4.1843. 
[25] H. Sabzian, H.Gharib, and A.Maleki, "A strategic framework for identifying the critical factors of 4G technology diffusion in I.R. Iran-A Fuzzy DEMATEL approach," Computers and Society (cs.CY) 2018, arXiv:1807.03542 [cs.CY]

[26] D. Uhlir, P. Sedlacek and P. Masek, "A New Data Processing Platform for LTE-Advanced Network in Indoor Envirronments," Elektro Revue, vol. 20, no. 6, pp. 181-191, 2018.

\section{BIOGRAPHIES OF AUTHORS}

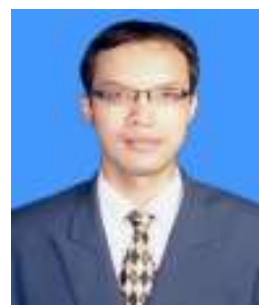

Setiyo Budiyanto is an Associate Professor in Electrical Engineering, Universitas Mercu Buana. He received his Ph.D in Electrical Engineering, Universitas Indonesia (2016). Currently he is active as a Lecturer at Universitas Mercu Buana, Jakarta, Indonesia. He conducts some research in the fields of Digital-Advanced Wireless Communication (D-AWC).

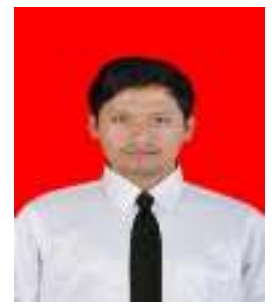

Erman Al Hakim received his ST. In Electrical Engineering, National Institute of Technology (ITENAS) Bandung, Indonesia.

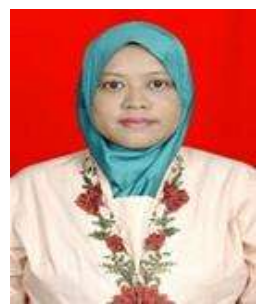

Fajar Rahayu I. M received her Master of Engineering (MT) degree in Electrical Engineering, Universitas Indonesia. She currently teaches at Universitas Pembangunan Nasional "Veteran", Jakarta, Indonesia. 